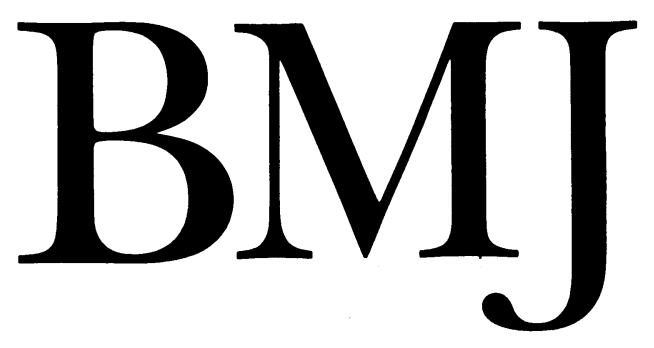

\title{
Multiple sclerosis: nature or nurture?
}

\author{
New evidence reaffirms the importance of environmental factors
}

The most intriguing feature about multiple sclerosis is that its occurrence varies with latitude. Although there are important exceptions, people of European origin are generally at higher risk if they live further from the equator. ${ }^{12}$ For decades doctors have been mapping the distribution of multiple sclerosis, fired by a conviction that the latitude effect must hold a key to the origin of the commonest disabling illness that affects adults in their prime.

Clearly, latitude itself cannot determine risk, so there has been a long search for an environmental cause. ${ }^{1-3}$ Climatic factors, diet, trace elements, exposure to animals, infections, and even cosmic radiation have been studied-but, like Cinderella's slipper, the evidence never fits exactly. In a study of American veterans, for example, several climatic factors seemed to influence the risk of multiple sclerosis when analysed alone; yet after adjustment for latitude their effects were found to be due to their correlation with this variable. ${ }^{4}$

A genetic influence was suspected long ago, mainly because of familial aggregation and large racial differences. ${ }^{56}$ Only one case of multiple sclerosis has been reported in a black South African, ${ }^{7}$ and the disease is also rare in Maoris, ${ }^{89}$ Hungarian gypsies, ${ }^{10}$ and other groups. Japanese and black Americans have a lower risk than their white counterparts, ${ }^{11}{ }^{12}$ although black people also experience some gradient in risk with latitude. ${ }^{13}$ Interest in genetic factors was fuelled by recognition of associations with certain HLA antigens (especially HLA-DR2 $)^{1415}$ and by the results of twin studies. ${ }^{16} 17$ In a Canadian study 26\% (7/27) of monozygotic twin pairs but only $2 \%(1 / 43)$ of dizygotic twin pairs were concordant for multiple sclerosis. ${ }^{16}$

In 1986 Ebers and Bulman reported that the geographical distribution of multiple sclerosis in the United States closely paralleled the distribution of people with a northern European (especially Scandinavian) background. ${ }^{18}$ The notion that the north-south gradient reflects genetic susceptibility was supported by a study in Britain, which found a correlation between the prevalence of multiple sclerosis and the frequency of HLA-DR2 in the population of different regions. ${ }^{19}$ The American results have not been published in detail and it would be unwise to accept the British conclusion without a more critical analysis: Swingler and Compston used prevalence data of widely varying quality collected over nearly 40 years, and the correlation was largely due to the results for the Orkneys (for which the frequency of HLA-DR2 could only be estimated) and north east Scotland. ${ }^{19}$ Surprisingly, studies of individuals in these places show no significant association between the relevant antigen and risk of multiple sclerosis. ${ }^{20} 21$ Nevertheless, the conclusions about the United States and Britain are widely quoted and the idea has grown that the explanation for the latitude gradient lies not in the environment but in population genetics.

Such a conclusion would be unlikely to satisfy those familiar with the global epidemiology of multiple sclerosis, and in particular with the results of studying migrants. ${ }^{12}$ Two reports published recently may rekindle interest in the environment. The first analyses results from studies in nine regions of Australia and New Zealand, all of which are closer to the equator than any part of the British Isles. ${ }^{22} \mathrm{~A}$ northsouth gradient had been found in New Zealand ${ }^{23}$; but, although environmental factors were presumed to be important, a genetic influence could not be excluded because southern New Zealand had a particularly high proportion of Scottish immigrants. Scots are generally held to be unusually susceptible to multiple sclerosis, although there is little evidence that they are any more susceptible than other British people (independently of geography). Comparison of all the Australasian data (excluding those on indigenous people) showed a striking association between the occurrence of multiple sclerosis and latitude, with the disease being seven times commoner in southern New Zealand than in tropical Queensland. There was no association with the proportion of people with surnames beginning with "Mac" or "Mc" or with the population frequency of HLA-DR2. Queensland has a higher proportion of people with HLA-DR2 than southern England, ${ }^{1922}$ yet the prevalence of multiple sclerosis in tropical Queensland is barely more than a tenth of that in Sutton. ${ }^{24} 25$

The second study exploits an important natural experiment in Britain. Previous work showed that immigrants from the Indian subcontinent, Africa, and the West Indies have a low risk of multiple sclerosis. ${ }^{26}$ Elian et al now report that children of these immigrants born in Britain have a high prevalencesimilar to that in other English residents. ${ }^{27}$ The magnitude of the risk is surprising in view of the differences between racial groups in the United States. In studies of this kind it is difficult to estimate risks precisely because of the small numbers of cases and problems in calculating expected numbers. Despite such uncertainties the results provide powerful evidence for the importance of some exogenous factor acquired in childhood.

Instead of pitting genes against geography, the attack on multiple sclerosis should use the classic epidemiological 
model of agent, host, and environment ${ }^{28}$ Research that allows for interplay among these factors is likely to be most productive. ${ }^{29} \mathrm{We}$ already know much about the environments in which multiple sclerosis is common and about relevant host factors (including those with a genetic basis). The agent(s) remains a mystery, although an infectious agent has long been suspected. More than 20 viruses have been linked with multiple sclerosis over the years, but in no case has the association proved causal. ${ }^{30}$ Recent reports implicating a retrovirus have not been confirmed. ${ }^{31-33}$ Alter et al suggested that multiple sclerosis might be an age dependent host response to measles and other childhood infections. ${ }^{34} 35$

Another lesson from the history of epidemiology is that diseases may be preventable before their causes are properly understood. Thus the Royal Navy knew how to prevent scurvy more than a century before the discovery of vitamins, and John Snow's work led to steps to control cholera long before the cholera vibrio was identified. ${ }^{28}$ Some optimists hope that the vaccination programmes against measles will lead to a decline in multiple sclerosis. That remains to be seen, but the search for environmental factors should continue.

D C G SKEGG

Professor of Preventive and Social Medicine,

University of Otago,

Dunedin,

New Zealand

1 Acheson ED. The epidemiology of multiple sclerosis. In: Matthews WB, ed. McAlpine's multiple sclerosis. Edinburgh: Churchill Livingstone, 1985: 3-46.

2 Kurtzke JF. Epidemiology of multiple sclerosis. In: Vinken PJ, Bruyn GW, Klawans HL, Koetsier JC, eds. Demyelinating diseases. Amsterdam: Elsevier, 1985: 259-87. (Handbook of clinical neurology; vol 47.)

3 Wynn DR, Rodriguez M, O'Fallon WM, Kurland LT. Update on the epidemiology of multiple sclerosis. Mayo Clin Proc 1989;64:808-17.

4 Norman JE, Kurtzke JF, Beebe GW. Epidemiology of multiple sclerosis in US veterans. 2. Latitude, climate and the risk of multiple sclerosis. $\mathcal{F}$ Chronic Dis 1983;36:551-9.

5 Spielman RS, Nathanson N. The genetics of susceptibility to multiple sclerosis. Epidemiol Rev 1982;4:45-65

6 Acheson ED. Epidemiology of multiple sclerosis. Br Med Bull 1977;33:9-14.

7 Bhigiee AI. Multiple sclerosis in a black patient. $S$ Afr Med F 1987;72:873-5.

8 Miller DH, Hornabrook RW, Dagger J, Fong R. Ethnic and HLA patterns related to multiple sclerosis in Wellington, New Zealand. $\mathcal{F}$ Neurol Neurosurg Psychiatry 1986;49:43-6.
Skegg DCG, Corwin PA, Craven RS, Malloch JA, Pollock M. Occurrence of multiple sclerosis in the north and south of New Zealand. $\mathcal{F}$ Neurol Neurosurg Psychiatry 1987;50:134-9.

10 Palffy G. MS in Hungary, including the gypsy population. In: Kuroiwa Y, Kurland LT, eds. Multiple sclerosis east and west. Basel: Karger, 1982: 149-57.

11 Detels R, Visscher BR, Malmgren RM, Coulson AH, Lucia MV, Dudley JP. Evidence for lower susceptibility to multiple sclerosis in Japanese-Americans. Am f Epidemiol 1977;105:303-10.

2 Morariu MA, Linden M. Multiple sclerosis in American blacks. Acta Neurol Scand 1980;62:180-7.

13 Kurtzke JF, Beebe GW, Norman JE. Epidemiology of multiple sclerosis in US veterans: 1. Race, sex, and geographic distribution. Neurology 1979;29:1228-35.

14 Batchelor JR. Immunological and genetic aspects of multiple sclerosis. In: Matthews WB, ed. McAlpine's multiple sclerosis. Edinburgh: Churchill Livingstone, 1985: 281-301.

$15 \mathrm{McD}$ conald WI. The mystery of the origin of multiple sclerosis. 7 Neurol Neurosurg Psychiatry 1986;49:113-23.

16 Ebers GC, Bulman DE, Sadovnick AD, et al. A population based study of multiple sclerosis in twins. N Englf Med 1986;315:1638-42.

17 Kinnunen E, Juntunen J, Ketonen L, et al. Genetic susceptibility to multiple sclerosis. A co-twin study of a nationwide series. Arch Neurol 1988;45:1108-11.

18 Ebers GC, Bulman D. The geography of MS reflects genetic susceptibility [Abstract]. Neurology 1986;36(suppl 1): 108 .

19 Swingler RJ, Compston DAS. The distribution of multiple sclerosis in Britain. 7 Neurol Neurosurg Psychiatry 1986;49:1115-24.

20 Poskanzer DC, Terasaki PI, Prenney LB, Sheridan JL, Park, MS. Multiple sclerosis in the Orkney and Shetland Islands. 3: Histocompatibility determinants. F Epidemiol Community Health 1980;34:253-7.

21 Francis DA, Batchelor JR, McDonald WI, et al. Multiple sclerosis in northeast Scotland. Brain 1987;110:181-96.

22 Miller DH, Hammond SR, McLeod JG, Purdie G, Skegg DCG. Multiple sclerosis in Australia and New Zealand: Are the determinants genetic or environmental? $\mathcal{F}$ Neurol Neurosurg Psychiatry 1990;53:903-5.

23 Fawcett J, Skegg DCG. Geographic distribution of MS in New Zealand: evidence from hospital admissions and deaths. Neurology 1988;38:416-8.

24 Hammond SR, de Wytt C, Maxwell IC, et al. The epidemiology of multiple sclerosis in Queensland, Australia. F Neurol Sci 1987;80:185-204.

25 Williams ES, McKeran RO. Prevalence of multiple sclerosis in a south London borough. BMf 1986;293:237-9.

26 Dean G, Brady R, McLoughlin H, Elian M, Adelstein AM. Motor neurone disease and multiple sclerosis among immigrants to Britain. British fournal of Preventive and Social Medicine 1977;31:141-7.

27 Elian M, Nightingale S, Dean G. Multiple sclerosis among United Kingdom born children of immigrants from the Indian subcontinent, Africa and the West Indies. 7 Neurol Neurosurg Psychiatry 1990;53:906-11.

28 Lilienfeld AM, Lilienfeld DE. Foundations of epidemiology. 2nd ed. New York: Oxford University Press, 1980.

29 Compston DAS, Vakarelis BN, Paul E, McDonald WI, Batchelor JR, Mims CA. Viral infection in patients with multiple sclerosis and HLA-DR matched controls. Brain 1986;109:325-44.

30 Johnson RT. Viral aspects of multiple sclerosis. In: Vinken PJ, Bruyn GW, Klawans HL, Koetsier JC, eds. Demyelinating diseases. Amsterdam: Elsevier, 1985: 319-36. (Handbook of clinical JC, eds. Demyelinat

31 Koprowski H, DeFreitas EC, Harper ME, et al. Multiple sclerosis and human T cell lymphotropic retroviruses. Nature 1985;318:154-60.

32 Weinshenker BG, Dekaban G, Rice GPA. Retroviruses and multiple sclerosis. 1. Analysis of seroreactivity by Western blot and radioimmune assay. Neurology 1990;40:1251-3.

33 Oksenberg JR, Mantegazza R, Sakai K, Bernard CCA, Steinman L. HTLV-1 sequences are not detected in peripheral blood genomic DNA or in brain cDNA of multiple sclerosis patients. Ann Neurol 1990;28:574-7.

34 Alter M. Is multiple sclerosis an age-dependent host response to measles? Lancet 1976;i:456-7.

35 Alter $M$, Zhen-xin Z, Davanipour Z, et al. Multiple sclerosis and childhood infections. Neurology 1986;36:1386-9.

\section{Picking up the tab for erythropoietin}

\section{General practitioners should prescribe it-just as they prescribe growth hormone}

One of the satisfactions of renal medicine is that chronic dialysis works. This treatment has kept some patients alive for more than 20 years. Nevertheless, survival is not cheap for government or patient. Maintenance haemodialysis or continuous ambulatory peritoneal dialysis costs $£ 10000-£ 12000$ a year, and about 8000 patients receive such treatment each year in the United Kingdom. Only recently has the struggle for sufficient dialysis facilities ended: the memory of "negative selection"-patients left to die of chronic renal failure - is still fresh. ${ }^{12}$ About a quarter of patients receiving dialysis still feel unwell because of anaemia caused by erythropoietin deficiency. Treatment with erythropoietin is available, but it is very expensive. A year's treatment for one patient costs $£ 3000-£ 5000$. Now a new battle is enjoined.

Taylor and colleagues have presented their findings in a group of patients receiving dialysis before, during, and after an eight week course of maintenance erythropoietin (p 272). ${ }^{3}$ The hormone was provided for trial purposes by the manufacturers. Because funds were not available to purchase further supplies, treatment had to be stopped. In all 12 patients the wretched symptoms of erythropoietin deficiency anaemia recurred, with an appreciable psychological morbidity.
Regrettably these are not isolated observations; many British renal units experience similar difficulties. It is not easy to estimate how many patients have the difficulties described by Taylor et al. The suppliers estimate that about 1300 patients have been treated with free erythropoietin made available for clinical trials and believe that most patients continue to enjoy the benefits of the hormone purchased from renal budgets. Yet their estimate is difficult to reconcile with Taylor et al's paper and what one hears on the grapevine. Certainly not all those who need erythropoietin are receiving it; perhaps 200-300 patients are missing out. Renal budgets that are underfunded (and hence overspent) are to blame. The treatment is successful, ${ }^{45}$ and the lack of funds to purchase supplies is scandalous. Money from a general hospital budget spent on erythropoietin would reduce the available acute sector funds even further. The Department of Health has, however, made it clear that central funding will not be provided for this desirable hormone.

Faced with these difficulties, what should doctors do? Blood transfusions, though ameliorating symptoms for a few weeks, are not the answer. Supplies are short, repeated transfusion leads to iron overload, and most important is the 